\title{
Closed-system programmed-temperature pyrolysis on $n$-octadecane: Implications for the conversion of oil to gas
}

\author{
Haizu Zhang, ${ }^{1,2 *}$ Ansong Geng, ${ }^{1}$ YongQiang Xiong,${ }^{1}$ JinZHONG LiU $^{1}$ and JinPING LiU ${ }^{1}$ \\ ${ }^{1}$ State Key Laboratory of Organic Geochemistry, Guangzhou Institute of Geochemistry, Chinese Academy of Sciences, \\ Guangzhou 510640, China \\ ${ }^{2}$ Graduate School of the Chinese Academy of Sciences, Beijing 100039, China
}

(Received June 6, 2007; Accepted April 21, 2008)

\begin{abstract}
The aim of this work is to determine the molecular and stable carbon isotope compositions of pyrolysates from normal octadecane and, then, to study methane generation kinetic and carbon isotope fractionation of gaseous hydrocarbons generated from $n$-octadecane cracking. Pyrolyses were carried out in an anhydrous closed system (gold tubes) under a constant pressure of $50 \mathrm{MPa}$ at heating rates of $20^{\circ} \mathrm{C} / \mathrm{h}$ and $2{ }^{\circ} \mathrm{C} / \mathrm{h}$. Results show that secondary cracking of pyrolysates from $n$-octadecane largely contributes to the amount of methane generation, much more than primary cracking of $n$ octadecane. Cracking and polymerization at relatively low temperatures and disproportionation reactions leading to light hydrocarbons and polyaromatic hydrocarbons at high temperatures are probable causes for the carbon isotope reversal of gaseous hydrocarbons that is commonly observed in pyrolysis experiments. This study of methane generation kinetics suggests that $n$-alkane hydrocarbon cracking begins to generate methane at $170^{\circ} \mathrm{C}$ but a great deal would be generated at $200^{\circ} \mathrm{C}$ in sedimentary basins.
\end{abstract}

Keywords: $n$-octadecane, pyrolysis experiment, gaseous hydrocarbon, stable carbon isotope, kinetic

\section{INTRODUCTION}

There are two major types of natural gas: microbial gas and thermogenic gas. Gas generation from the late cracking of crude oils in reservoirs is considered an important source of thermogenic gas (Ungerer et al., 1988; Horsfield et al., 1992; Behar et al., 1999; Lorant et al., 2000). Crude oils are complex mixtures made up chiefly of hydrocarbons, and as a special gas precursor, show gasgeneration characteristics different from those of kerogen and coal. Therefore, the study of oil cracking (including the gas-generating potential of the oil, and chemical and isotopic compositions of residual oil) can not only improve our understanding of the genesis of natural gases, but also provide practical application tools for source identification and quantitative assessment of oil-derived gases. Numerous authors (Smith et al., 1971; Ungerer et al., 1988; Horsfield et al., 1992; Behar et al., 1992; Pepper and Dodd, 1995; Tsuzuki et al., 1999) have therefore attempted to determine how oil composition changes with increasing thermal stress with an emphasis on quantitative models accounting for the transformations observed

\footnotetext{
*Corresponding author (e-mail: haizuzhang@sina.com)

Copyright () 2008 by The Geochemical Society of Japan.
}

in crude oils. It is widely accepted that the thermal evolution of oils is controlled by the kinetics of cracking reactions, which is generally modeled by the Arrhenius equation (Tissot and Welte, 1984). This allows petroleum geochemists to simulate experimentally the lowtemperature, long residence time natural processes by operating at higher temperatures than those normally occurring during geological periods.

The history of experiments designed to understand oil cracking is a long one, including experiments on whole rocks and kerogens (Behar et al., 1992; Evans and Felbeck, 1983; Saxby and Riley, 1984; Monin et al., 1990; Price, 1993; Vandenbroucke et al., 1999), oils (Ungerer et al., 1988; Horsfield et al., 1992; Bjorøy et al., 1988; Schenk et al., 1997; Hill et al., 2003; Tang et al., 2005), coals (Gaschnitz et al., 2001), and model compounds (Behar and Vandenbroucke, 1996; Behar et al., 1999, 2002; Lorant et al., 2000; Sackett, 1978; Domine, 1989, 1991; Jackson et al., 1995). These experimental simulations have been carried out at the molecular level. As a consequence, more elaborate categorization of the resultant pyrolysates has been achieved, leading to a better understanding of the interplays between gas generation and carbon isotopic fractionation of methane through the use of various model compounds. While earlier studies focused on yields and $\delta^{13} \mathrm{C}$ values of gaseous products, this paper will pay more attention to the hydrocar- 
bon decomposition from a detailed analysis of the residual liquid hydrocarbons. Normal octadecane $\left(n-\mathrm{C}_{18}\right)$ was chosen as an appropriate model compound because it is relatively abundant in many crude oils irrespective of organic source type, it is of intermediate molecular weight, and there is a relatively rich literature on the behavior of this homolog compound at higher temperatures (Sackett, 1978; Jackson et al., 1995; Behar and Vandenbroucke, 1996; Frank and Sackett, 1969). This compound was selected to be used for molecular kinetic simulating experiments to improve our understanding of the kinetic effect of oil cracking and the stable carbon isotopic composition of gaseous hydrocarbons. As oil-derived gases are generally formed in relatively closed paleo-oil reservoirs and under relatively high temperatures, a closed pyrolysis system was used in this study to model the hydrocarbon generation via secondary cracking.

\section{EXPERIMENTAL}

\section{Heating procedure}

The sample used in the experiment was $n$-octadecane (GR) purchased from Tokyo Kasei Kogyo Co. Ltd. Its $\delta^{13} \mathrm{C}$ value is $-33.7 \%$ (PDB), determined using a Delta Plus XL GC-IRMS instrument. Pyrolyses were carried out in gold tubes ( $40 \mathrm{~mm}$ length, $4 \mathrm{~mm}$ i.d., and $0.2 \mathrm{~mm}$ thick) under anhydrous conditions, the basic experimental details of which have been described by Xiong et al. (2004). Two heating rates, $20^{\circ} \mathrm{C} / \mathrm{h}$ and $2{ }^{\circ} \mathrm{C} / \mathrm{h}$ respectively, were selected for the pyrolysis of the $n-\mathrm{C}_{18}$ sample in this study.

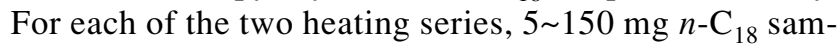
ples were loaded into gold tubes. The loaded tubes were first flushed with argon for several minutes to ensure the complete removal of air, and then sealed under an atmosphere of argon. These gold tubes were placed in 12 stainless steel autoclaves respectively, and in each autoclave two parallel gold tubes were placed for the chemical and isotopic composition analyses of pyrolysates to be performed. All autoclaves were heated in a uniform oven. Pressure was kept at $50 \mathrm{MPa}$ throughout the pyrolysis process. At last, the autoclaves were removed from the oven one after another when the desired temperatures were reached and then quenched in a cold water bath. The thermal maturity of the experiments is expressed as equivalent vitrinite reflectance (\%Ro) calculated using the experimental times, temperatures and the Easy\%Ro procedure (Sweeney and Burnham, 1990).

\section{Gas analysis}

Cleaned gold tubes were placed in a vacuum line at $10^{-5} \mathrm{MPa}$ connected to an Agilent $6890 \mathrm{~N}$ gas chromatograph. After isolating the extraction line from the vacuum pump, the tube was pierced with a needle, allowing the gas to be volatilized into the line. Then, molecular char- acterization and quantification of the total gas fraction was performed by gas chromatography. The external standard method was applied to the quantification of gas components. The GC conditions were as follows: the column was kept at $40^{\circ} \mathrm{C}$ for $6 \mathrm{~min}$, programmed to $180^{\circ} \mathrm{C}$ at a $25^{\circ} \mathrm{C} / \mathrm{min}$ rate, and finally kept at $180^{\circ} \mathrm{C}$ for $4 \mathrm{~min}$.

After molecular characterization and quantification, the gaseous fraction was subjected to GC-IRMS analysis for measurement of the carbon isotope compositions of methane, ethane and propane. GC-IRMS analyses were performed on a VG Isochrom II instrument. The GC was equipped with a Poraplot $\mathrm{Q}$ column $(30 \mathrm{~m} \times 0.32 \mathrm{~mm}$ i.d). Helium was used as the carrier gas. Column head pressure was $8.5 \mathrm{Psi}$. A temperature program of $50^{\circ} \mathrm{C}(2$ $\min )$ to $180^{\circ} \mathrm{C}(8 \mathrm{~min})$ at $25^{\circ} \mathrm{C} / \mathrm{min}$ was used. The carbon isotopic ratio of $\mathrm{CO}_{2}$ reference gas was calibrated using NBS 22 oil as a reference material using continuous flow isotope ratio mass spectrometry (Thermo Quest Flash EA 1112 Series elemental analyser combined with a Delta Plus XL mass-spectrometer). Carbon isotope ratios for individual gaseous hydrocarbons were calculated using $\mathrm{CO}_{2}$ as a reference gas that was automatically introduced into the IRMS at the beginning and end of each analysis. Reported isotopic data represented the averages of at least three replicate analyses, and the variance between each run was less than $0.3 \%$. All carbon isotopic values were reported in per mil (\%o) relative to the PDB standard.

\section{Analysis of the $C_{7+}$ extract}

In order to avoid the loss of light hydrocarbons, the second tube was cooled with liquid nitrogen, then the gold tube was cut into pieces and added to a vial $(4 \mathrm{~mL})$ containing dichloromethane solution. After extraction for more than 24 h by stirring, the solid residue was allowed to settle for several hours, and then the extract was filtered. The filter and residue together with gold pieces were washed with solvent repeatedly. The dichloromethane extract was divided into two fractions, the weight of which was determined accurately, and the dichloromethane insolubles were measured as cokes. After adding the internal standard of deuterated- $n \mathrm{C}_{15}$, the first fraction was analyzed on a Finnigan Trace GC Ultra gas chromatograph for the total $\mathrm{C}_{7}-\mathrm{C}_{18}$ fraction. The second part of the dichloromethane extract was evaporated, weighed and analyzed by GC/MS. The GC conditions were the following: Quadax column $(50 \mathrm{~m} \times 0.25 \mathrm{~mm})$, initial temperature of $80^{\circ} \mathrm{C}$ for $2 \mathrm{~min}$, final temperature of $290^{\circ} \mathrm{C}$ for $30 \mathrm{~min}$, and heating rate from 80 to $290^{\circ} \mathrm{C}$ at $4^{\circ} \mathrm{C} /$ min. The GC/MS conditions were the following: The column used was a DB-5MS capillary column $(60 \mathrm{~m} \times 0.32$ $\mathrm{mm} \times 0.25 \mu \mathrm{m}) \mathrm{kept}$ at $60^{\circ} \mathrm{C}$ for $5 \mathrm{~min}$, programmed to $200^{\circ} \mathrm{C}$ at a $3^{\circ} \mathrm{C} / \mathrm{min}$ rate, then programmed to $290^{\circ} \mathrm{C}$ at a $6^{\circ} \mathrm{C} / \mathrm{min}$ rate, and finally kept at $290^{\circ} \mathrm{C}$ for $30 \mathrm{~min}$. 


\section{RESULTS}

Hydrocarbon gas yield

We divided the pyrolysis gas into five groups: $\mathrm{C}_{1}, \mathrm{C}_{2}$, $\mathrm{C}_{3}, \mathrm{C}_{4-5}$ and $\mathrm{H}_{2}$. The cumulative yields of gaseous hydrocarbons in pyrolysates at two heating rates are summarized in Table 1. The changes in trends of gaseous hydrocarbon yields with increasing thermal stress (pyrolysis time and temperature) are shown in Fig. 1. At both heating rates, gas yields are very small at low levels of thermal stress $\left(\%\right.$ Ro $\left.<1.0,400^{\circ} \mathrm{C}\right)$. Methane yield increases continuously to $\sim 870 \mathrm{~mL} / \mathrm{g}$ at $\%$ Ro $\sim 4.2\left(580^{\circ} \mathrm{C}, 2^{\circ} \mathrm{C} / \mathrm{h}\right)$ with increasing thermal stress, and remains essentially constant up to the final pyrolysis level $\left(596^{\circ} \mathrm{C}, 2^{\circ} \mathrm{C} / \mathrm{h} ; R o\right.$ $=4.4 \%$ ) (Table 1, Fig. 1). Yields of $\mathrm{C}_{2}, \mathrm{C}_{3}$ also increase as thermal stress increases and reach a maximum at $\% R o$ $2.1 \sim 2.2\left(20^{\circ} \mathrm{C} / \mathrm{h}: 500^{\circ} \mathrm{C}, 2^{\circ} \mathrm{C} / \mathrm{h}: 461^{\circ} \mathrm{C}\right.$, Table 1$)$. Above $\%$ Ro 2.2, yields of $\mathrm{C}_{2}, \mathrm{C}_{3}$ start to decrease, and by $\% R o$ $\sim 4.4\left(2{ }^{\circ} \mathrm{C} / \mathrm{h}, 596^{\circ} \mathrm{C}\right)$ cracking of $\mathrm{C}_{2}$ is almost complete, whereas $\mathrm{C}_{3}$ is no longer present. The $\mathrm{C}_{4-5}$ yield reaches a maximum of $\sim 75 \mathrm{~mL} / \mathrm{g}$ at $\% R o \sim 1.8\left(2^{\circ} \mathrm{C} / \mathrm{h}, 442^{\circ} \mathrm{C}\right)$. Above $\%$ Ro $\sim 1.8$, The $\mathrm{C}_{4-5}$ yields decrease, and by $\% R o$ $\sim 4.2\left(2^{\circ} \mathrm{C} / \mathrm{h}, 580^{\circ} \mathrm{C}\right)$ cracking of $\mathrm{C}_{4-5}$ is complete (Table 1, Fig. 1).

\section{Distribution of liquid hydrocarbon}

In this article, the discussion is focused on the results obtained using a $20^{\circ} \mathrm{C} / \mathrm{h}$ heating rate. The mass balances obtained for selected experiments at a $20^{\circ} \mathrm{C} / \mathrm{h}$ heating rate are given in Table 2 .

The GC traces and total ion current plots of the total $\mathrm{C}_{7+}$ extracts of the residual liquid hydrocarbons after $n$ $\mathrm{C}_{18}$ cracking at a heating rate of $20^{\circ} \mathrm{C} / \mathrm{h}$ are given in Figs. 2 and 3 . The conversion of $n-\mathrm{C}_{18}$ is defined as follows: conversion $=1-($ residual reactant/initial reactant $)$ and is expressed in weight percent (Fig. 2). Results show that the main temperature range for thermal cracking of $n-\mathrm{C}_{18}$ extends from 350 to $480^{\circ} \mathrm{C}$, corresponding to a maturity range of 0.9 to $2.0 \%$ Ro (Table 2 , Fig. 1). Below $420^{\circ} \mathrm{C}$ $(\%$ Ro $=1.1)$, little cracking was observed for $n-\mathrm{C}_{18}$ as indicated by the low degree of conversion of $n-\mathrm{C}_{18}$ (Fig. 2 ). The yield of $\mathrm{C}_{7}-\mathrm{C}_{17} n$-alkanes in the pyrolysates increases to $\sim 276 \mathrm{mg} / \mathrm{g}$ at $460^{\circ} \mathrm{C}(\% R o=1.5)$ with increasing temperature, with $\mathrm{C}_{18+} n$-alkanes appearing above $440^{\circ} \mathrm{C}$. The occurrence of $\mathrm{C}_{18+} n$-alkanes indicates polymerization concurring with $n-\mathrm{C}_{18}$ cracking. Subsequently, liquid $n$-alkanes disappear when heating temperature reaches $480^{\circ} \mathrm{C}$. Figure 2 shows that, above $460^{\circ} \mathrm{C}$, with the decrease of $n$-alkane contents, cyclization and aromatization reactions of $n$-alkanes form abundant aromatic compounds dominated by benzene, naphthalene, phenanthrene, pyrene and their alkyl derivatives (Fig. 3, Table 2). Thus, cyclization and aromatization of $n$-alkanes at higher maturity potentially contribute to the aromatic hydrocarbon budget in the geological samples.

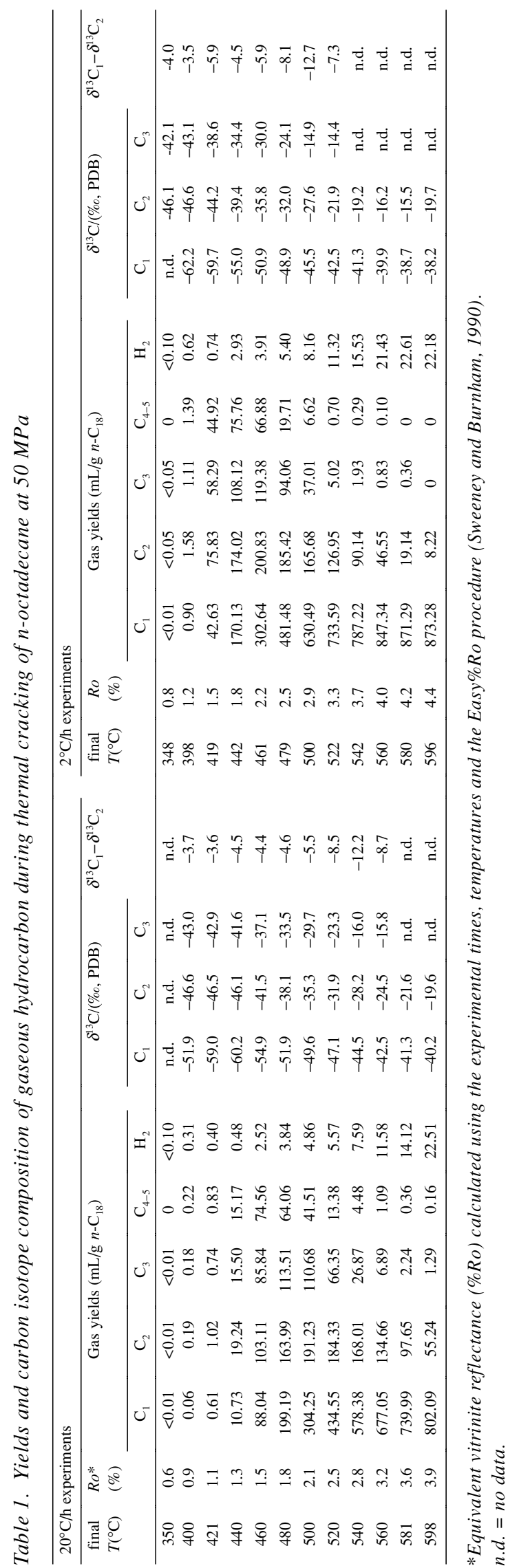

Implications from on $n$-octadecane pyrolysis 

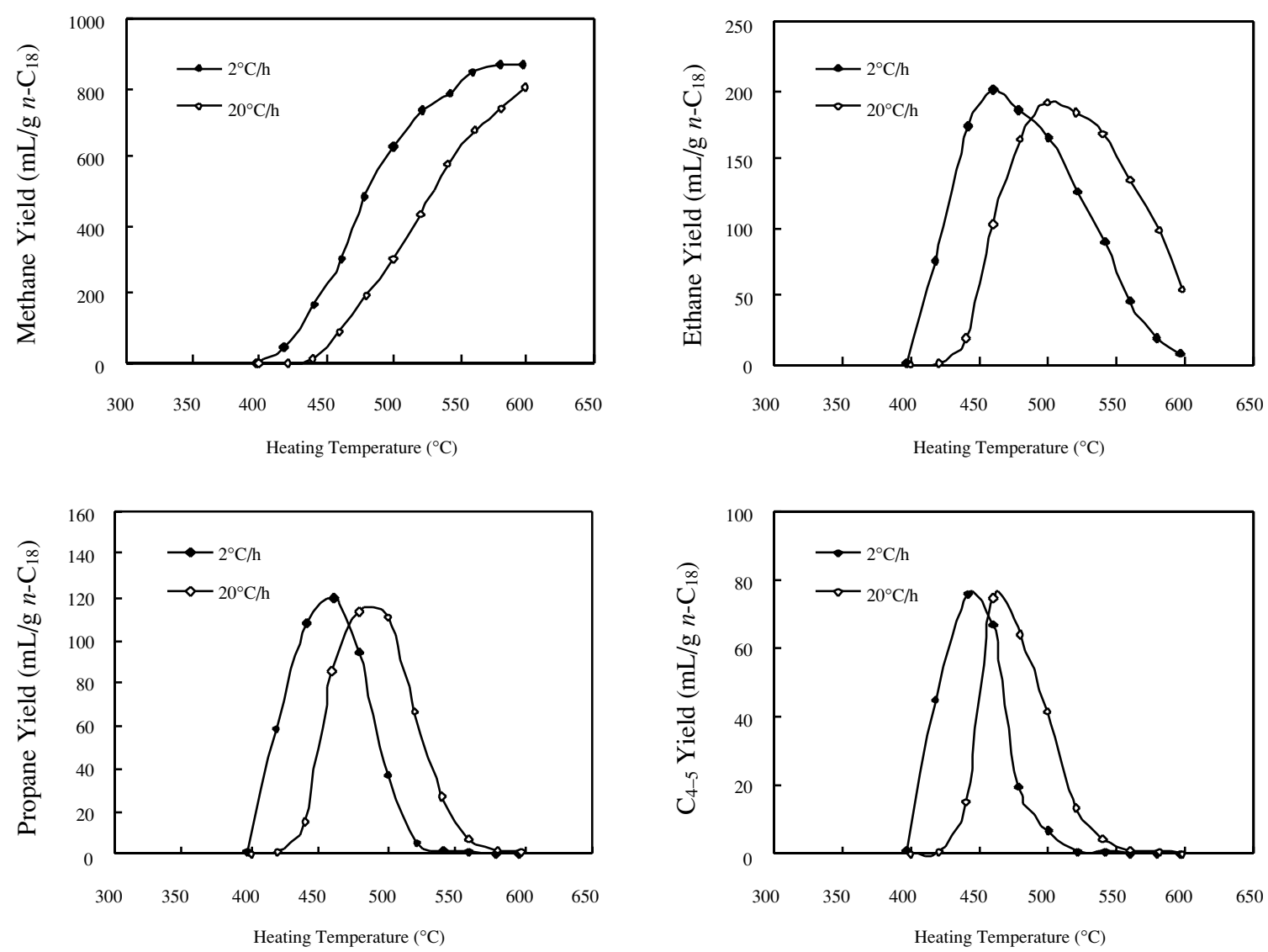

Fig. 1. Cumulative yields $\left(\mathrm{mL} / \mathrm{g} n-C_{18}\right)$ of gaseous hydrocarbon fractions $C_{1}, C_{2}, C_{3}$ and $C_{4-5}$ during $n$-octadecane cracking at two heating rates $\left(2\right.$ and $\left.20^{\circ} \mathrm{C} / \mathrm{h}\right)$.

Table 2. Selected mass balances obtained during thermal cracking of $n-C_{18}$ at heating rate $20^{\circ} \mathrm{C} / \mathrm{h}$

\begin{tabular}{rrcrccccr}
\hline $\begin{array}{r}\text { final } \\
T\left({ }^{\circ} \mathrm{C}\right)\end{array}$ & $\begin{array}{r}\mathrm{C}_{1}-\mathrm{C}_{5} \\
(\mathrm{mg} / \mathrm{g})\end{array}$ & $\begin{array}{c}\mathrm{H}_{2} \\
(\mathrm{mg} / \mathrm{g})\end{array}$ & $\begin{array}{r}\mathrm{C}_{7}-\mathrm{C}_{17} \\
(\mathrm{mg} / \mathrm{g})\end{array}$ & $\begin{array}{c}\mathrm{C}_{18} \\
(\mathrm{mg} / \mathrm{g})\end{array}$ & $\begin{array}{c}\mathrm{C}_{18+} \\
(\mathrm{mg} / \mathrm{g})\end{array}$ & $\begin{array}{c}\text { Aromatics } \\
(\mathrm{mg} / \mathrm{g})\end{array}$ & $\begin{array}{c}\text { Coke } \\
(\mathrm{mg} / \mathrm{g})\end{array}$ & $\begin{array}{r}\text { Total } \\
(\mathrm{mg} / \mathrm{g})\end{array}$ \\
\hline 400 & 1.28 & 0.03 & $<1.00$ & 986.23 & 0 & 0 & 0 & 987.54 \\
421 & 5.61 & 0.04 & 4.23 & 970.15 & $<1.00$ & 0 & 0 & 980.03 \\
440 & 106.11 & 0.04 & 158.18 & 688.01 & 25.82 & 28.61 & 0 & 1006.77 \\
460 & 575.48 & 0.23 & 275.92 & 50.92 & 5.36 & 112.42 & 8.42 & 1028.75 \\
480 & 757.06 & 0.34 & 53.18 & 23.04 & $<1.00$ & 204.32 & 51.46 & 1089.40 \\
500 & 801.65 & 0.43 & 0 & 0 & 0 & 167.35 & 182.45 & 1151.88 \\
520 & 723.38 & 0.50 & 0 & 0 & 0 & 129.24 & 249.23 & 1102.35 \\
540 & 702.97 & 0.68 & 0 & 0 & 0 & 88.32 & 302.68 & 1094.65 \\
560 & 680.39 & 1.03 & 0 & 0 & 0 & 50.26 & 343.35 & 1075.03 \\
581 & 664.71 & 1.26 & 0 & 0 & 0 & 38.15 & 350.21 & 1054.33 \\
598 & 649.86 & 2.01 & 0 & 0 & 0 & 35.24 & 358.16 & 1045.27 \\
\hline
\end{tabular}

In addition, some black cokes are also observed in the high-temperature pyrolysates. The yield of cokes is zero below $460^{\circ} \mathrm{C}$ and increases very quickly to a maximum of almost $360 \mathrm{mg} / \mathrm{g}$ with heating temperature increasing (Table 2). They cannot be analyzed by GC and GC/MS due to their insolubility.
$C_{1}-C_{3}$ hydrocarbon gas carbon isotopes

Methane, ethane and propane carbon isotope values determined in the experiments are listed in Table 1. As shown in Table 1 and Fig. 4 , the measured $\delta^{13} \mathrm{C}$ values of cumulative methane, ethane and propane at the heating rate of $20^{\circ} \mathrm{C} / \mathrm{h}$ range from $-51.9 \%$ to $-40.2 \%$ o, $-46.6 \%$ o 
$421^{\circ} \mathrm{C}$
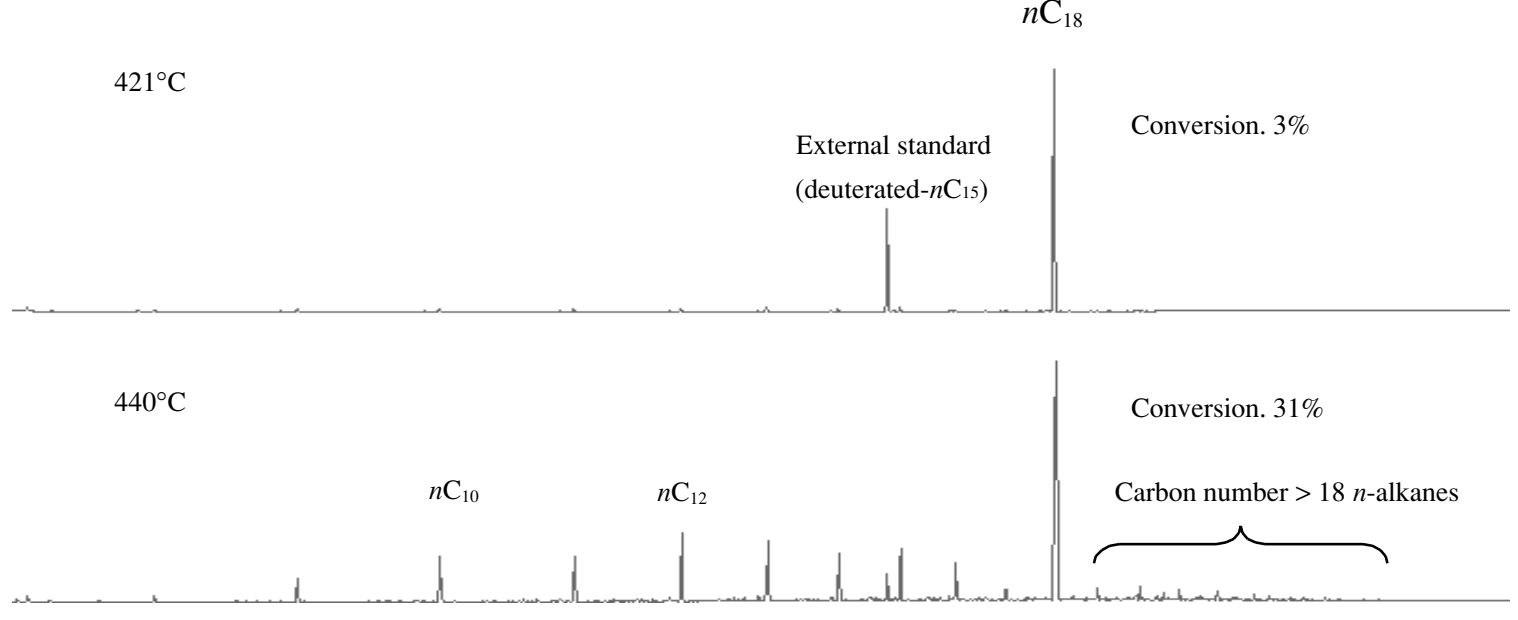

$460^{\circ} \mathrm{C}$

Conversion. $95 \%$

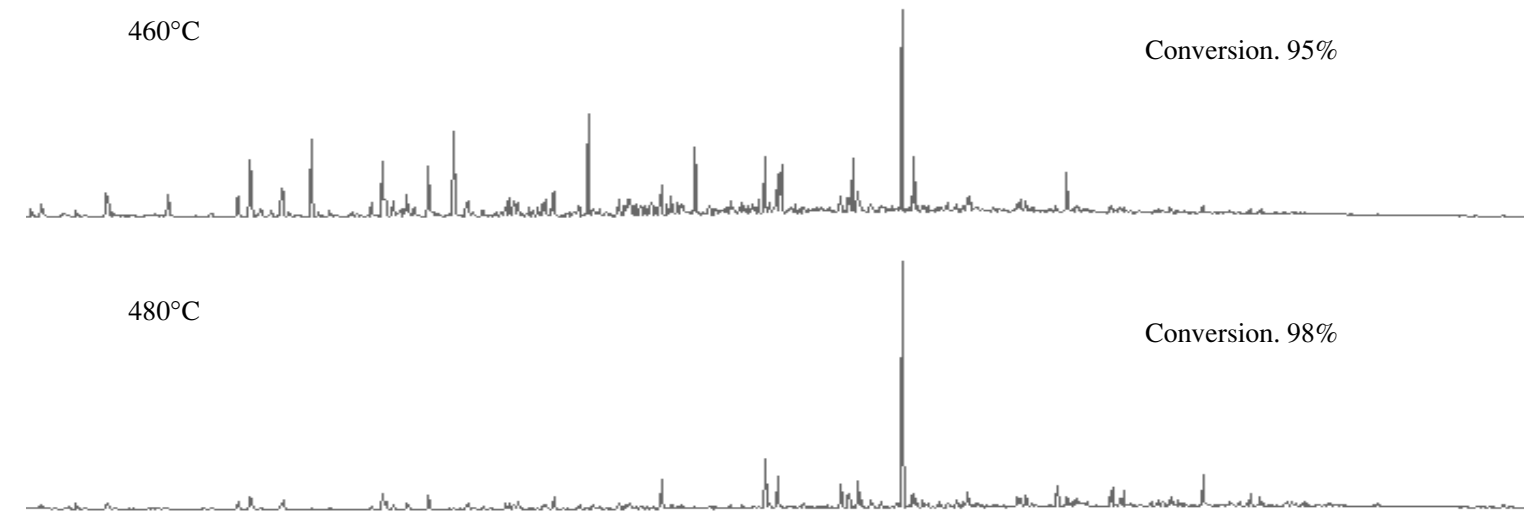

Fig. 2. Gas chromatogram of residual liquid hydrocarbons during $n$-octadecane cracking at heating rate $20^{\circ} \mathrm{C} / \mathrm{h}$.

Table 3. $\delta^{13} \mathrm{C}$ values of $n$-octodecane and its pyrolysis products at heating rate $20^{\circ} \mathrm{C} / \mathrm{h}(\%$ o, $P D B)$

\begin{tabular}{cccccccccccc}
\hline Temperature & $n \mathrm{C}_{8}$ & $n \mathrm{C}_{9}$ & $n \mathrm{C}_{10}$ & $n \mathrm{C}_{11}$ & $n \mathrm{C}_{12}$ & $n \mathrm{C}_{13}$ & $n \mathrm{C}_{14}$ & $n \mathrm{C}_{15}$ & $n \mathrm{C}_{16}$ & $n \mathrm{C}_{17}$ & $n \mathrm{C}_{18}$ \\
\hline unheated & - & - & - & - & - & - & - & - & - & - & -33.7 \\
$350^{\circ} \mathrm{C}$ & - & - & - & - & - & - & - & - & - & - & -33.6 \\
$420^{\circ} \mathrm{C}$ & - & - & - & - & - & - & - & - & - & - & -33.1 \\
$440^{\circ} \mathrm{C}$ & -32.8 & -32.5 & -30.6 & -30.3 & -30.3 & -30.3 & -30.3 & -30.3 & -28.6 & -30.7 & -28.4 \\
\hline
\end{tabular}

to $-19.6 \%$ and $-43.0 \%$ to $-15.8 \%$, respectively. However, at the heating rate of $2{ }^{\circ} \mathrm{C} / \mathrm{h}$ the isotopic compositions range from $-62.2 \%$ o to $-38.2 \%$, $-46.6 \%$ o to $-15.5 \%$ o and $-43.1 \%$ to $-14.4 \%$, respectively. During the early stages of the pyrolysis process, methane, ethane and propane become slightly depleted in ${ }^{13} \mathrm{C}$. After reaching a minimum $\delta^{13} \mathrm{C}$, methane, ethane and propane become enriched in ${ }^{13} \mathrm{C}$ as thermal evolution increases. At higher pyrolysis temperatures ethane becomes depleted in ${ }^{13} \mathrm{C}$ again (Fig. 4, Table 1). The first reversal in the carbon isotopes of methane, ethane and propane occurs at the thermal evolution of $\% R o \sim 1.2$. The second reversal in the carbon isotopes of ethane occurs at the thermal evolution of $\% R o \sim 4.2\left(580^{\circ} \mathrm{C}, 2^{\circ} \mathrm{C} / \mathrm{h}\right)$, and the second reversal in the carbon isotopes of propane occurs at the approximately thermal evolution of \%Ro $\sim 2.8\left(540^{\circ} \mathrm{C}\right.$, $20^{\circ} \mathrm{C} / \mathrm{h}$, or $500^{\circ} \mathrm{C}, 2^{\circ} \mathrm{C} / \mathrm{h}$ ).

Carbon isotopic composition of residual liquid hydrocarbons

As liquid hydrocarbons were present in the pyrolysates only within a very narrow range of pyrolysis temperatures (Fig. 2), quality isotopic data was obtained only from the $440^{\circ} \mathrm{C}$ pyrolysates. Table 3 displays the $\delta^{13} \mathrm{C}$ values 


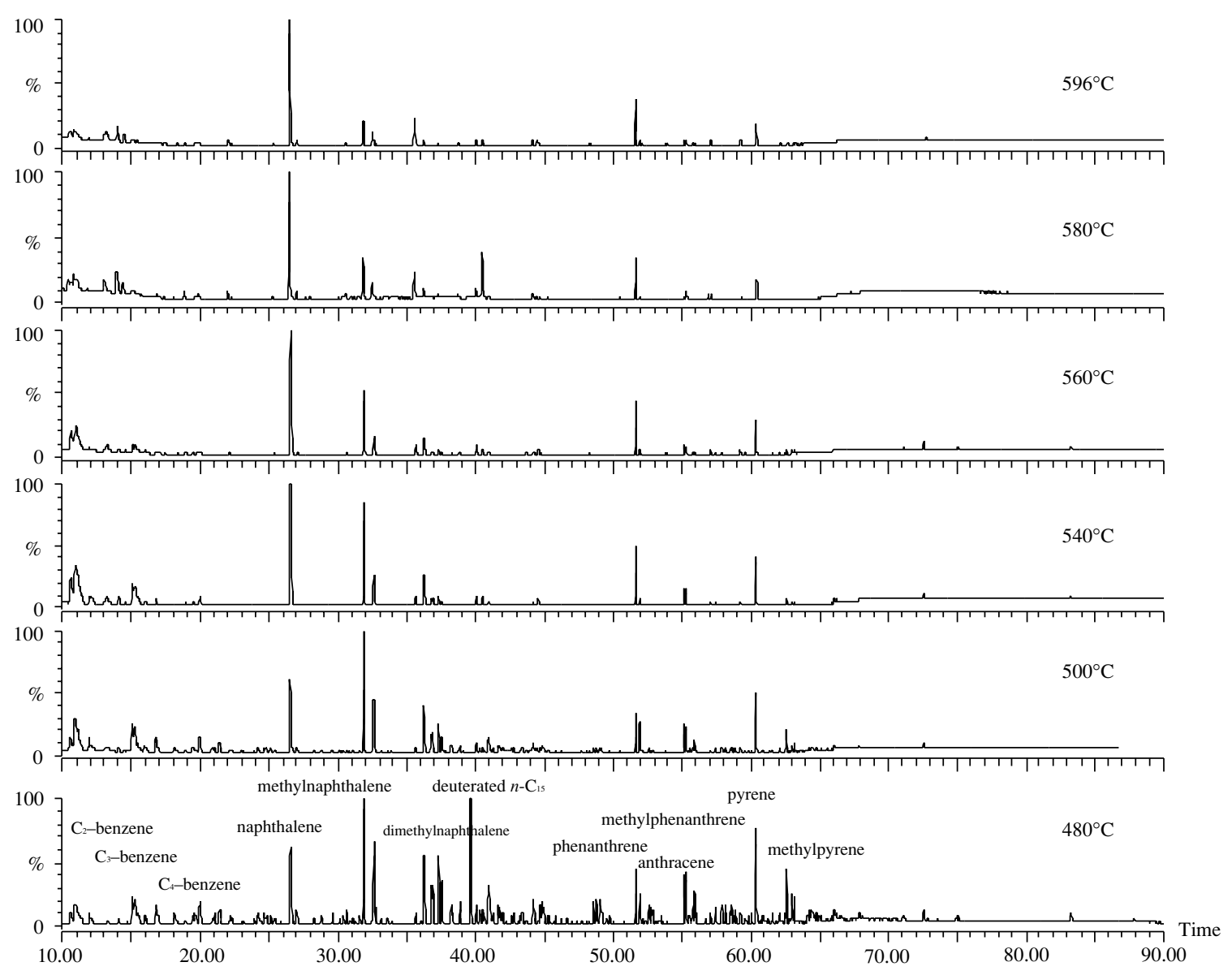

Fig. 3. Total ion current plot of residual liquid hydrocarbons during $n$-octadecane cracking at heating rate $20^{\circ} \mathrm{C} / \mathrm{h}$.

of $n-\mathrm{C}_{18}$ at different pyrolysis temperatures and those of other liquid $n$-alkanes in the $440^{\circ} \mathrm{C}$ pyrolysates. The results indicate that with thermal cracking, the $\delta^{13} \mathrm{C}$ value of $n-\mathrm{C}_{18}$ varies up to $5.3 \%$ at $440^{\circ} \mathrm{C}$, and those of the resultant $n$-alkanes change up to $4.4 \%$, with relative depletion of ${ }^{13} \mathrm{C}$ in the lower molecular weight components.

\section{Discussion}

Controls on n-octadecane cracking products and geochemical implications

Methane and coke increase continuously as thermal stress increases, which shows that methane and coke are the thermodynamically stable products during $n-\mathrm{C}_{18}$ cracking. The yield of coke is zero when the conversion of $n-\mathrm{C}_{18}$ is below $95 \mathrm{wt} \%$ and increases very quickly for higher conversions (Table 2, Fig. 2). This means that coke is not produced directly by $n-\mathrm{C}_{18}$ cracking but results from secondary reactions. It is considered that the precursors of coke formation are likely to be polyaromatics generated by late dehydrogenation of initial hydroaromatics when conversion is higher than $90 \mathrm{wt} \%$ (Behar and

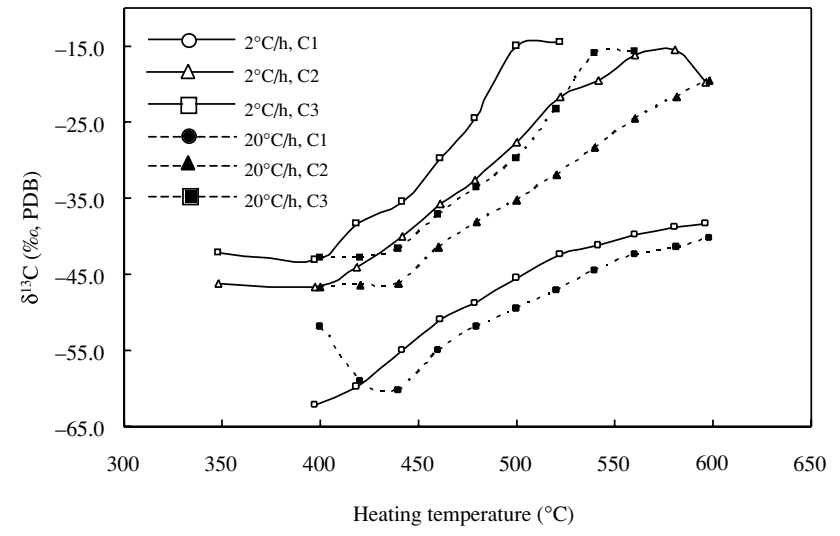

Fig. 4. Carbon isotope variations of methane, ethane and propane with heating temperature.

Vandenbroucke, 1996). This experiment shows that maximum methane generation rate of $n-\mathrm{C}_{18}$ is mainly restricted by hydrogen content. The $\mathrm{H} / \mathrm{C}$ ratio of $n-\mathrm{C}_{18}$ is about 2.1 , whereas for the ultimate product methane it is 4 . If hy- 
drogen in $n-\mathrm{C}_{18}$ is completely transferred to methane, the maximum amount of methane that can be generated corresponds to $60 \%$ of the original mass of $n-\mathrm{C}_{18}$ according to a stoichiometric calculation. In the pyrolysis experiment, maximum methane generation rate determined is $873 \mathrm{~mL} / \mathrm{g}$ (Table 1), that is about $60 \%$ based on a calculation using the ideal gas equation of state. Therefore, the determined value is in good agreement with the theoretical result.

On the basis of the above characteristics of pyrolysates, it can be inferred that at the early stage of $n$ $\mathrm{C}_{18}$ cracking, obvious polymerization occurs accompanied by little cracking. Yields of intermediate pyrolysis products (including $\mathrm{C}_{2-5}, \mathrm{C}_{6-17}, \mathrm{C}_{18+}$ and aromatic compounds) increase because the rate of formation of a product is greater than the rate of decomposition. After $480^{\circ} \mathrm{C}$ (or $R o>2.0 \%$ ), liquid $n$-alkanes disappear and have no more significant contribution to late gaseous hydrocarbon generation (Fig. 2). According to total ion current plots in Fig. 3, alkylation, dealkylation, and aromatic ring condensation are among the most prevalent chemical reactions occurring within the high temperature pyrolysates, resulting in gaseous hydrocarbons as one of the key byproducts for the disproporationation reactions.

The carbon number distribution of $n$-alkyl molecules including $n$-alkanes in modern organisms and sediments is controlled mainly by the source, with significant variation in carbon isotope ratio for $n$-alkanes with different carbon number. Such differences in mature source rocks and crude oils tend to diminish with increasing thermal maturity. The experiment with $n-\mathrm{C}_{18}$ indicates that hydrocarbon cracking in petroleum reservoirs and/or in less efficiently impellent source rocks is one of the main causes for the compositional and isotope variation of gaseous hydrocarbon. In addition to plant lignins, cyclization and aromatization of $n$-alkanes is also a possible source for aromatic hydrocarbons, especially in marine source rocks. Therefore, some aromatic biomarker parameters based on isomer thermal stability, such as the Methyphenanthrene Index, will probably be affected by this additional input at relatively high maturity levels. As source rocks for gases derived from oil-cracking in China are generally of old age and with high maturity, it remains to be seen how the distributions and carbon isotopic compositions of residual hydrocarbons in these source rocks can be utilized for thermal maturity determination and oil-source correlation.

\section{Carbon isotope fractionation of gaseous hydrocarbons}

Chemical and isotopic compositions of natural gases are important indicators for determining their source type and thermal maturity, nevertheless compositional and isotopic data are limited for gases and do not always provide a unique interpretation. The difference (isotopic sepa- ration) between ethane and propane $\delta^{13} \mathrm{C}\left(\delta^{13} \mathrm{C}_{\mathrm{ethane}}{ }^{-}\right.$ ${ }^{13} \mathrm{C}_{\text {propane }}$ ) has been used as a maturity indicator (James, 1983, 1990; Lorant et al., 1998). For $n-C_{18}$ cracking, our results show that the separation between $\delta^{13} \mathrm{C}_{\text {ethane }}$ and $\delta^{13} \mathrm{C}_{\text {propane }}$ increases in a closed system as thermal stress increases (Table 1) like that described for oil cracking by Hill et al. (2003). In addition, the heating rate has a significant effect on the carbon isotope variation of gaseous hydrocarbons, e.g. with the increase of the heating rate, the $\delta^{13} \mathrm{C}$-trend of pyrolysis gas will shifts toward higher temperatures (Fig. 4).

It is known that gaseous hydrocarbons derived from kerogen or oils usually become enriched in ${ }^{13} \mathrm{C}$ with increasing thermal maturity. In pyrolysis experiments, however, an obvious reversal in the carbon isotopes of gaseous hydrocarbons often occurs at the early stage of methane generation (Lorant et al., 1998; Tang et al., 2000; Cramer et al., 2001) and the gaseous hydrocarbons generated at high temperatures are relatively depleted in ${ }^{13} \mathrm{C}$ again (Cramer et al., 1998, 2001). These reversals were also observed in our experiments with $n-\mathrm{C}_{18}$ (Fig. 4).

Because the initial reactant in our experiments involves only $n-\mathrm{C}_{18}$, only $\mathrm{C}-\mathrm{C}$ bond cracking would have an effect on stable carbon isotope fractionation. Preferential cracking of ${ }^{12} \mathrm{C}-{ }^{12} \mathrm{C}$ bonds in $n-\mathrm{C}_{18}$ leads to the formation of alkyl moieties that are relatively depleted in ${ }^{13} \mathrm{C}$. Consequently, high molecular weight $n$-alkanes and aromatic hydrocarbons generated by these alkyl moieties are also depleted in ${ }^{13} \mathrm{C}$ compared with the original $n$ $\mathrm{C}_{18}$. With increasing pyrolysis temperature, gaseous hydrocarbons generated from the cracking of these hydrocarbons would become depleted in ${ }^{13} \mathrm{C}$ compared to those directly from $n-\mathrm{C}_{18}$ cracking. Therefore, the first carbon isotope reversal of gaseous hydrocarbons is probably a result of cracking and polymerization of hydrocarbons at relatively low temperatures. At higher temperature, $n$ alkanes disappear and the cracking of alkylated aromatics becomes one of the main sources for gaseous hydrocarbon generation. Lorant et al. (2000) suggested that alkylated aromatics occur widely in source rocks and oil reservoirs and are also an important source of methane in natural gases, and that at high maturity, demethylation of aromatic hydrocarbons and opening of aromatic rings are possible reasons for methane depleted in ${ }^{13} \mathrm{C}$. The result of this experiment confirms that disproportionation reactions leading to light hydrocarbons and polyaromatic hydrocarbons at high temperatures are probable causes for the second carbon isotope reversal of gaseous hydrocarbons. In addition, as methane is accumulated in a closed system, late generated methane with depleted ${ }^{13} \mathrm{C}$ has no obvious effect on the overall methane carbon isotope data due to its relatively low yield (Fig. 4). In contrast the reversal can be seen clearly at high temperature pyrolysis experiments with an open system, because the reac- 


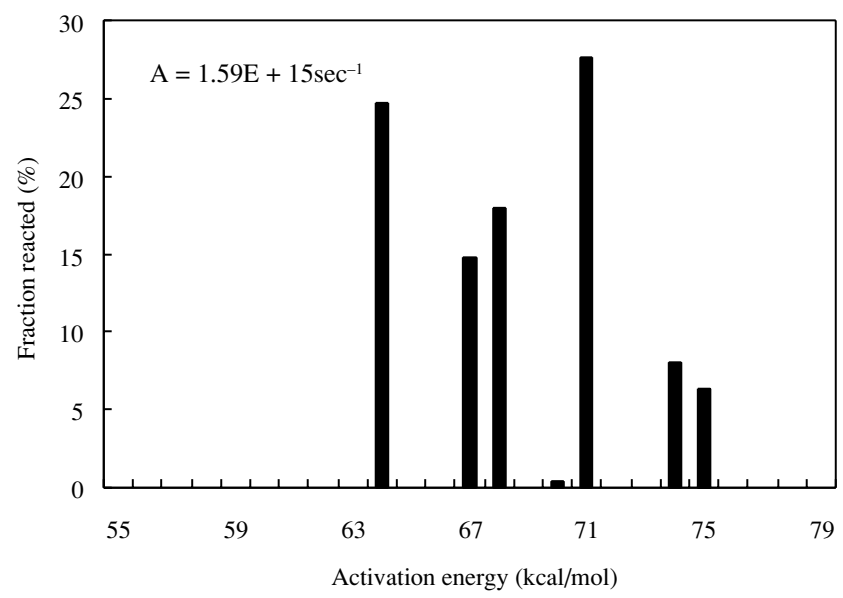

Fig. 5. Activation energy distribution ( $\mathrm{kcal} / \mathrm{mol}$ ) and frequency factor $(1 / \mathrm{sec})$ for methane generation. The kinetic calculations are based on the cumulative formation curves from Fig. 1.

tions occur instantaneously (Cramer et al., 1998, 2001).

The initial isotopic ratio of the methane-generating part of $n-\mathrm{C}_{18}\left(\delta^{13} \mathrm{C}_{\text {o,prec }}\right)$ can be derived from the cumulative methane isotope ratio at the ultimate stage of $n-\mathrm{C}_{18}$ decomposition (Cramer et al., 1998). So it can be inferred that the $\delta^{13} \mathrm{C}_{\text {o,prec }}$ of $n-\mathrm{C}_{18}$ is $-38.2 \%$ in this pyrolysis experiment. The bulk $\delta^{13} \mathrm{C}$ value of $n$ - $\mathrm{C}_{18}$ used in this experiment is $-33.7 \%$, and its methane generating part is about $60 \%$ ultimately, the rest can be considered as residual carbon. Thus, the residual part accounts for approximately $40 \%$ of initial reactant and its $\delta^{13} \mathrm{C}$ value should be around $-27.0 \%$ by mass balance calculation. As the residue is enriched in ${ }^{13} \mathrm{C}$ by up to $6.7 \%$ with respect to the initial reactant in the experiment, the $\delta^{13} \mathrm{C}$ values of solid bitumen thermally generated in paleo-oil reservoir cannot be directly correlated with those of crude oils.

\section{Kinetics of methane generation}

Methane is a product of the cracking of $n-\mathrm{C}_{18}, \mathrm{C}_{18+}$, $\mathrm{C}_{6-17}, \mathrm{C}_{2-5}$ and aromatic compounds and accumulates because it is a stable end product. The rate of methane generation varies depending on the reactant and the level of thermal stress. Because methane generation during $n$ $\mathrm{C}_{18}$ cracking is a very complicated kinetic process involving multiple precursors, we have adopted a kinetic model based on a discrete activation energy model to fit the data for both temperatures (Tang et al., 1996). It can be assumed here that the generation of methane can be adequately described by a set of $n$ parallel first-order reactions, with activation energies $E_{\alpha, i}$ and a common frequency factor, $A$. In this paper the calculation of kinetic parameters for methane generation was carried out based on the data in table 1 with Kinetics (2000), a program

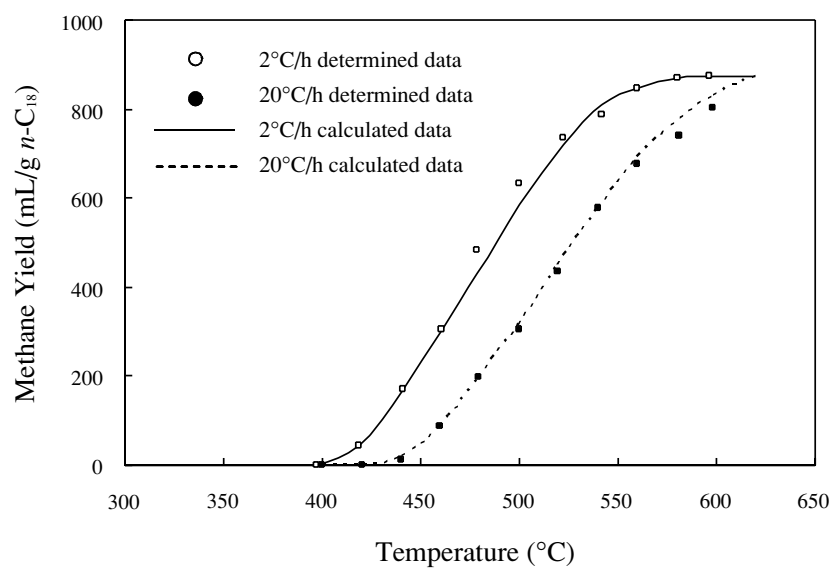

Fig. 6. The match between measured and calculated methane yield.

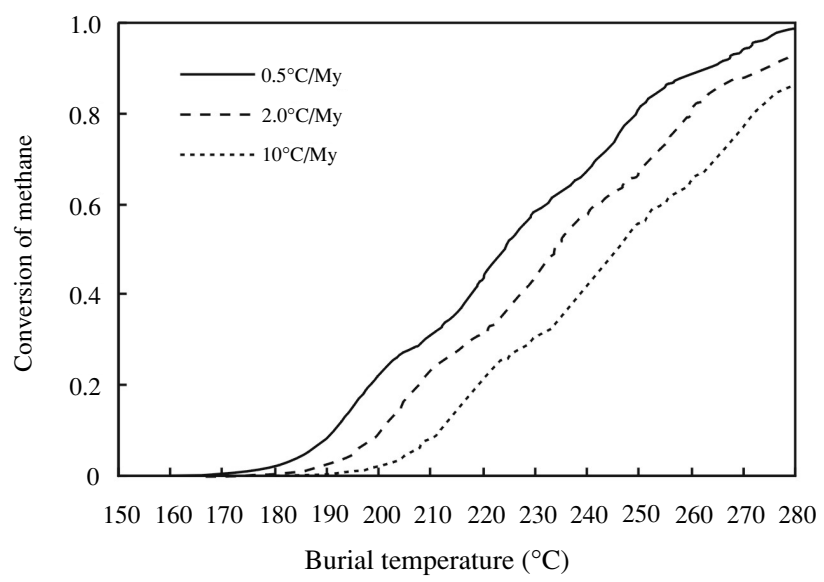

Fig. 7. Cumulative formation of methane predicted for different geological heating rates. Quantities have been calculated on the basis of Fig. 5.

developed by Xiong et al. (2004). The activation energy distribution and frequency factor obtained for methane formation during $n-\mathrm{C}_{18}$ cracking are shown in Fig. 5. Figure 6 displays the measured data and the simulation results calculated by using these kinetic parameters in Fig. 5. As shown in Fig. 6, the calculated methane yields agree well with the measured values.

On the basis of the calculated activation energies and frequency factor, one can extrapolate heating rates from laboratory conditions to geologic conditions (Tang et al., 1996; Ungerer and Pelet, 1987). Figure 7 shows predicted methane generation for geologic heating rates from 0.5 to $10^{\circ} \mathrm{C} / \mathrm{My}$. According to these results, gas from saturated hydrocarbons cracking begins to generate at $170^{\circ} \mathrm{C}$ during geological times but significant generation is ob- 
served only at $200^{\circ} \mathrm{C}$. This is consistent with observations on $n-\mathrm{C}_{25}$ by Behar and Vandenbroucke (1996) in which the degradation window for heavy $n$-alkanes lies beyond $170^{\circ} \mathrm{C}$. This means that secondary cracking of saturated hydrocarbons in reservoir oils does not produce a large proportion of gas even in deep reservoirs. When compared with methane generation from the methylated aromatics (Lorant et al., 2000), which generating methane occurs in the range $160-200^{\circ} \mathrm{C}$ under a geothermal gradient of $1.25^{\circ} \mathrm{C} / \mathrm{My}$, it is clear that aromatic compounds constitute an important source of gas in sedimentary basins, much more than $n$-alkanes. Consequently numerous studies suggest that the main source of gas accumulations is the demethylation of kerogen or cracking of the NSO compounds inside source rocks in reservoirs (Behar et al., 1992, 1995; Chung and Sackett, 1979).

It should be noted that only thermal factors are considered in this study. In a more realistic geological system, other factors such as the presence of water, minerals and thermochemical sulphate reduction (TSR) could greatly influence the thermal evolution of sedimentary organic matter and reservoired petroleum bitumens in gaseous hydrocarbon generation. These factors can not only accelerate hydrocarbon generation rate, but also probably change reaction processes (Mango, 2000). Burnham et al. (1997) have shown that mixture effect delays the thermal cracking of $n-\mathrm{C}_{16}$ when mixed with various reservoir oils. Therefore, simulation experiments under more realistic conditions should be performed to advancing our understanding the conversion of oil to gas.

\section{CONCLUSION}

The following conclusions can be drawn from the present investigation:

(1) Thermal cracking of $n-\mathrm{C}_{18}$ in closed system leads to the production of gaseous hydrocarbons, liquid hydrocarbons, aromatic compounds and coke. The amount of pyrolysis gas is not high until the degradation of secondary lighter hydrocarbons resulting from primary cracking of $n$ - $\mathrm{C}_{18}$ occurs. With increasing temperature, secondary cracking of $\mathrm{C}_{2-5}$, liquid hydrocarbons and aromatic compounds contribute substantially to methane generation. Methane and coke are stable end products from $n$ $\mathrm{C}_{18}$ cracking under the experimental conditions imposed.

(2) At the initial stage of $n$-octadecane cracking, cracking and polymerization at relatively low temperatures are probable causes for the first carbon isotope reversal of gaseous hydrocarbons. Significant amounts of aromatic hydrocarbons in geological samples can be formed as products of $n$-alkane cracking, and disproportionation reactions of these aromatics at high temperature is probably a main reason of the secondary carbon isotopic reversal of gaseous hydrocarbons.
(3) The study of methane generation kinetics shows that methane from $n$-alkane hydrocarbons cracking begins to generate at $170^{\circ} \mathrm{C}$ at geological timescales but substantial generation starts only at $200^{\circ} \mathrm{C}$. Compared with aromatic compounds, $n$-alkanes have a lesser methane-generating potential in reservoirs below $200^{\circ} \mathrm{C}$.

Acknowledgments - This work was supported financially by project of Chinese Academy of Sciences (Grant No. KZCX1SW-18-03) and the National Natural Science Foundation of China (Grant No. 40372070). We are very grateful to Profs. B. M. Krooss, Y. Tang and an anonymous reviewer for their helpful comments which have improved the manuscript.

\section{REFERENCES}

Behar, F. and Vandenbroucke, M. (1996) Experimental determination of the rate constants of the $n-\mathrm{C}_{25}$ thermal cracking at 120, 400, and 800 bars: Implications for highpressure/high-temperature prospects. Energy \& Fuels 10, 932-940.

Behar, F., Kressman, S., Rudkiewicz, J. L. and Vandenbrouke, M. (1992) Experimental simulation in a confined system and kinetic modeling of kerogen and oil cracking. Advances in Org. Geochem. Vol. 19 (Eckardt, C. B., Maxwell, J. R., Larter, S. R. and Manning, D. A. C., eds.), 173-189.

Behar, F., Vandenbroucke, M., Teerman, S. C. et al. (1995) Experimental simulation of gas generation from coals and a marine kerogen. Chem. Geol. 126, 247-260.

Behar, F., Budzinski, H., Vandenbroucke, M. and Tang, Y. (1999) Methane Generation from oil cracking: kinetics of 9-methylphenanthrene cracking and composition with other pure compounds and oil fractions. Energy \& Fuels 13, 471481.

Behar, F., Lorant, F., Budzinski, H. and Desavis, E. (2002) Thermal stability of alkylaromatics in natural systems: kinetics of thermal decomposition of dodecylbenzene. Energy \& Fuels 16, 831-841.

Bjorøy, M., Williams, J. A., Dolacater, D. L. and Winters, J. C. (1988) Variation in hydrocarbon distribution in artificially matured oils. Org. Geochem. 13, 901-913.

Burnham, A. K., Gregg, H. R. and Ward, R. L. et al. (1997) Decomposition kinetics and mechanism of $n$-hexadecane$1,2-{ }^{13} \mathrm{C}_{2}$ and dodec-1-ene-1,2- ${ }^{13} \mathrm{C}_{2}$ doped in petroleum and n-hexadecane. Geochim. Cosmochim. Acta 61, 3725-3737.

Chung, H. M. and Sackett, W. M. (1979) Use of stable carbon isotope compositions of pyrolytically derived methane as maturity indices for carbonaceous material. Geochim. Cosmochim. Acta 43, 1979-1988.

Cramer, B., Krooss, B. M. and Littke, R. (1998) Modeling isotope fractionation during primary cracking of natural gas: a reaction kinetic approach. Chem. Geol., 149, 235-250.

Cramer, B., Faber, E., Gerling, P. and Krooss, B. M. (2001) Reaction kinetics of stable carbon isotopes in natural gasinsights from dry, open system pyrolysis experiments. Energy \& Fuels 15, 517-532.

Domine, F. (1989) Kinetics of hexane pyrolysis at very high pressures. 1. Experimental study. Energy \& Fuels 3, 89- 
96.

Domine, F. (1991) High pressure pyrolysis of $n$-hexane, 2,4dimethylpentane and 1-phenylbutane. Is pressure and important geochemical parameter? Org. Geochem. 17, 619634.

Evans, R. J. and Felbeck, G. T., Jr. (1983) High temperature simulation of petroleum formation. 1. The pyrolysis of Green River shale. Org. Geochem. 4, 135-144.

Frank, D. J. and Sackett, W. M. (1969) Kinetic isotope effects in the thermal cracking of neopentane. Geochim. Cosmochim. Acta 33, 811-820.

Gaschnitz, R., Krooss, B. M., Gerling, P., Faber, E. and Littke, R. (2001) On-line pyrolysis-GC-IRMS: isotope fractionation of thermally generated gases from coals. Fuel 80, 2139-2153.

Hill, R. J., Tang, Y. and Kaplan, I. R. (2003) Insights into oil cracking based on laboratory experiments. Org. Geochem. 34, 1651-1672.

Horsfield, B., Schenk, H. J., Mills, N. and Welte, D. H. (1992) Closed-system programmed-temperature pyrolysis for simulating the conversion of oil to gas in a deep petroleum reservoir. Org. Geochem. 19, 191-204.

Jackson, K. J., Burnham, A. K., Braun, R. L. and Knauss, K. G. (1995) Temperature and pressure dependence of $n$ hexadecane cracking. Org. Geochem. 23, 941-953.

James, A. T. (1983) Correlation of natural gas by use of carbon isotopic distribution between components. Amer. Assoc. Petrol. Geol. Bull. 67, 1176-1191.

James, A. T. (1990) Correlation of reservoired gases using the carbon isotopic composition of wet gas components. Amer. Assoc. Petrol. Geol. Bull. 74, 1441-1458.

Lorant, F., Prinzhofer, A., Behar, F. and Huc, A. Y. (1998) Carbon isotopic and molecular constraints on the formation and the expulsion of thermogenic hydrocarbon gases. Chem. Geol., 147, 249-264.

Lorant, F., Behar, F. and Vandenbroucke, M. (2000) Methane generation from methylated aromatics: kinetic study and carbon isotope modeling. Energy \& Fuels 14, 1143-1155.

Mango, F. (2000) The origin of light hydrocarbons. Geochim. Cosmochim. Acta 64, 1265-1277.

Monin, J. C., Connan, J., Oudin, J. L. and Durand, B. (1990) Quantitative and qualitative experimental approach of oil and gas generation: Application to the North Sea source rocks. Org. Geochem. 16, 133-142.

Pepper, A. S. and Dodd, T. A. (1995) Simple kinetic models of petroleum formation. Part II: oil-gas cracking. Mar. Petrol. Geol. 12, 321-340.

Price, L. C. (1993) Thermal stability of hydrocarbons in nature: limits, evidence, characteristics and possible controls. Geochim. Cosmochim. Acta 57, 3261-3280.
Sackett, W. M. (1978) Carbon and hydrogen isotope effects during the thermocatalytic production of hydrocarbons in laboratory simulation experiments. Geochim. Cosmochim. Acta 42, 571-580.

Saxby, J. D. and Riley, K. W. (1984) Petroleum generation by laboratory-scale pyrolysis over six years simulating conditions in a subsiding basin. Nature 308, 177-179.

Schenk, H. J., di Primio, R. and Horsfield, B. (1997) The conversion of oil into gas in petroleum reservoirs. Part 1: Comparative kinetic investigation of gas generation from crude oils of lacustrine, marine and fluviodeltaic origin by programmed-temperature closed-system pyrolysis. Org. Geochem. 26, 467-481.

Smith, J. E., Erdman, J. G. and Morris, D. A. (1971) Migration, accumulation and retention of petroleum in the Earth. Proceedings of the 8th World Petroleum Congress, Vol. 2, pp. 13-26.

Sweeney, J. J. and Burnham, A. K. (1990) Evaluation of a simple model of vitrinite reflectance based on chemical kinetics. Amer. Assoc. Petrol. Geol. Bull. 74, 1559-1570.

Tang, Y., Jenden, P. D., Nigrini, A. et al. (1996) Modeling early methane generation in coal. Energy \& Fuels 10, 659-671.

Tang, Y., Perry, J. K., Jenden, P. D. and Schoell, M. (2000) Mathematical modeling of stable carbon isotope ratios in natural gases. Geochim. Cosmochim. Acta 64, 2673-2687.

Tang, Y., Huang, Y., Ellis, G., Wang, Y., Kralert, P., Gillaizeau, B., Ma, Q. and Hwang, R. (2005) A kinetic model for thermally induced hydrogen and carbon isotope fractionation of individual $n$-alkanes in crude oil. Geochim. Cosmochim. Acta 69, 4505-4520.

Tissot, B. P. and Welte, D. H. (1984) Petroleum Formation and Occurrence. 2nd ed., Springer-Verlag, Berlin.

Tsuzuki, N., Takeda, N., Suzuki, M. and Yokoi, K. (1999) The kinetic modeling of oil cracking by hydrothermal pyrolysis experiments. Int. J. Coal Geol. 39, 227-250.

Ungerer, P. and Pelet, R. (1987) Extrapolation of the kinetics of oil and gas formation from laboratory experiments to sedimentary basins. Nature 327, 52-54.

Ungerer, P., Behar, F., Villalba, M., Heum, O. R. and Audibert, A. (1988) Kinetic modelling of oil cracking. Org. Geochem. 13, 857-868.

Vandenbroucke, M., Behar, F. and Rudkiewicz, J. L. (1999) Kinetic modeling of petroleum formation and cracking: implications from the high pressure/high temperature Elgin Field (UK, North Sea). Org. Geochem. 30, 1105-1125.

Xiong, Y. Q., Geng, A. S. and Liu, J. Z. (2004) Kinetic simulating experiment combined with GC-IRMS analysis: Application to identification and assessment of coal-derived methane from Zhongba Gas Field (Sichuan Basin, China). Chem. Geol. 213, 325-338. 